\title{
Pemberdayaan Lembar Kerja Siswa untuk Meningkatkan Pembelajaran IPA pada Standar Kompetensi Mengidentifikasi Fungsi Organ Tubuh Manusia dan Hewan di Kelas V Semester II SDN 61 Karara Kota Bima Tahun Pelajaran 2019/2020
}

\author{
Siti Rukmini \\ SDN 61 Kota Bima, Bima, Indonesia \\ Fitri Ningsi* \\ STKIP Taman Siswa Bima, Bima, Indonesia \\ *Coresponding Author : ningsifitri899@gmail.com \\ Dikirim: 13-06-2021 ; Direvisi: 14-06-2021 ; Diterima: 14-06-2021
}

\begin{abstract}
Abstrak: Pemberdayaan Lembar Kerja Siswa Untuk Meningkatkan Pembelajaran IPA Pada Standar Kompetensi Mengidentifikasi Fungsi Organ Tubuh Manusia dan Hewan di Kelas V Semester II SDN 61 Kota Bima Tahun Pelajaran 2019/2020. Penelitian ini merupakan penelitian tindakan kelas (classroom action research) yang bertujuan untuk meningkatkan kualitas pembelajaran ipa pada standar kompetensi mengidentifikasi fungsi organ tubuh manusia dan hewan pada siswa kelas V semester II SDN 61 Kota Bima Tahun Pelajaran 2019/2020 dengan jumlah siswa 20 orang. Tehnik analisa data kuantitatifyang digunakan adalah analisis deskriptif yaitu skor rata-rata dan persentase, sedangkan analisis data kualitatif meliputi analisis hasil observasi yang dilakukan selama siklus I dan siklus II. Dalam proses pembelajaran, saat guru mengajar pelajaran IPA di Kelas V Semester II SDN 61 Karara Kota Bima khususnya pada standar kompetensi mengidentifikasi fungsi organ tubuh manusia dan hewan selalu terlihat peserta didik tidak aktif dalam mengikuti pelajaran, mereka terlihat tidak semangat dan tidak memiliki rasa antusias yang tinggi dalam mengikuti kegiatan pembelajaran di dalam kelas. Oleh karenanya guru bertugas mencari solusi atas permasalahan tersebut. dalam hal ini guru memberdayakan Lembar Kerja Siswa Untuk Meningkatkan Pembelajaran IPA Pada Standar Kompetensi Mengidentifikasi Fungsi Organ Tubuh Manusia dan Hewan di Kelas V Semester II SDN 61 Karara Kota Bima Tahun Pelajaran 2019/2020. Hasil penelitian ini menunjukan bahwa pemberdayaan Lembar Kerja Siswa Untuk Meningkatkan Pembelajaran IPA Pada Standar Kompetensi Mengidentifikasi Fungsi Organ Tubuh Manusia dan Hewan di Kelas V Semester II SDN 61 Karara Kota Bima Tahun Pelajaran 2019/2020 dapat meningkatkan kemampuan pembelajaran mengidentifikasi fungsi organ tubuh manusia dan hewan dalam pembelajaran Ilmu Pengetahuan Alam (IPA). Yakni terlihat dari nilai rata-rata siswa pada kondisi awal 62, nilai rata-rata siklus satu 67.35 dan pada siklus dua menjadi 84 hal ini telah melampaui KKM 70 dengan jumlah siswa yang tuntas sebanyak 17 orang dan yang tidak tuntas 3 orang dan ketuntasan klasikal yaitu $85 \%$.
\end{abstract}

Kata Kunci: Lembaran kerja siswa; prestasi; peningkatan

Abstract: Empowerment of Student Worksheets to Improve Science Learning on Competency Standards for Identifying the Functions of Human and Animal Organs in Class V Semester II SDN 61 Bima City in the 2019/2020 Academic Year. This research is a classroom action research that aims to improve the quality of learning science on competency standards to identify the functions of human and animal organs in class $\mathrm{V}$ semester II students of SDN 61 Bima City in the 2019/2020 academic year with a total of 20 students. Quantitative data analysis technique used is descriptive analysis, namely the average score and percentage, while qualitative data analysis includes analysis of observations made during cycle I and cycle II. In the learning process, when the teacher 
teaches science lessons in Class V Semester II SDN 61 Karara, Bima City, especially on competency standards to identify the functions of human and animal organs, it is always seen that students are not active in participating in lessons, they look unenthusiastic and do not have a strong sense of enthusiasm. high in participating in learning activities in the classroom. Therefore, the teacher is tasked with finding solutions to these problems. In this case, the teacher empowers Student Worksheets to Improve Science Learning on Competency Standards for Identifying the Functions of Human and Animal Organs in Class V Semester II SDN 61 Karara, Bima City in the 2019/2020 Academic Year. The results of this study show that empowering Student Worksheets to Improve Learning Science on Competency Standards for Identifying the Functions of Human and Animal Organs in Class V Semester II SDN 61 Karara Bima City in the 2019/2020 Academic Year can improve learning abilities to identify the functions of human and animal organs in learning Natural Sciences (IPA). That is seen from the average score of students in the initial conditions 62, the average value of cycle one 67.35 and in cycle two to 84 this has exceeded the KKM 70 with the number of students who completed as many as 17 people and who did not complete 3 people and classical completeness namely $85 \%$.

Keyworsd : worksheet; achievement; improvement

\section{PENDAHULUAN}

Pada saat guru mengajar pelajaran IPA di Kelas V Semester II SDN 61 Karara Kota Bima khususnya pada standar kompetensi mengidentifikasi fungsi organ tubuh manusia dan hewan selalu terlihat peserta didik tidak aktif dalam mengikuti pelajaran, mereka terlihat tidak semangat dan tidak memiliki rasa antusias yang tinggi dalam mengikuti kegiatan pembelajaran di dalam kelas. Proses belajar mengajar dikatakan berhasil jika sekitar $80 \%$ peserta didik telah mampu menguasai materi pelajaran yang telah disampaikan guru, jika masih kurang dari $80 \%$ maka proses belajar mengajar tidak berhasil, perlu dikaji ulang dimana letak kekurangan proses belajar mengajar tersebut. Dari hasil belajar peseta didik, belum dikatakan berhasil karena pencapaian hasil belajar hanya mencapai $60 \%$, sehingga perlu diadakan tindakan untuk meningkatkan hasil belajar peserta didik . Keberhasilan peseta didik dalam belajar bukan hanya dipengaruhi oleh keseriusan peseta didik dalam belajar, guru dalam mengajar juga merupakan hal yang penting dalam proses pembelajaran. Dari faktor guru mungkin guru tersebut belum menggunakan atau memberdayakan suatu cara dan metode yang tepat secara maksimal. Dalam pembelajaran IPA sebagaimana penulis paparkan di atas, bahwa ketidakberhasilan dalam proses pembelajaran dikarenakan cara dan tehnik guru dalam mengajar tidak optimal, penyampaiannya masih bersifat konvensioal, hanya berkisar ceramah dan mencatat materi pelajaran saja, akibatnya peserta didik tidak memiliki aktifitas, semuanya bersikap pasif sehingga tidak mampu meningkatkan hasil belajar juga tidak mampu menguasai materi pelajaran IPA yang telah disampaikan guru. Jika halhal demikian terus menerus berlangsung maka kemampuan siswa dalam mata pelajaran IPA khususnya pada standar kompetensi mengidentifikasi fungsi organ tubuh manusia dan hewan akan mengalami hambatan dan akhirnya tidak mampu mengaplikasikan ilmu mereka pada masyarakat dan lingkungannya. 


\section{METODE PENELITIAN}

Penelitian ini merupakan penelitian tindakan (action research), karena penelitian dilakukan untuk memecahkan masalah pembelajaran di kelas. Penelitian ini juga termasuk penelitian deskriptif, sebab menggambarkan bagaimana suatu teknik pembelajaran diterapkan dan bagaimana hasil yang diinginkan dapat dicapai. Dalam penelitian tindakan ini menggunakan bentuk guru sebagai peneliti, penanggung jawab penuh penelitian ini adalah guru. Tujuan utama dari penelitian tindakan ini adalah untuk meningkatkan hasil pembelajaran di kelas dimana guru secara penuh terlibat dalam penelitian mulai dari perencanaan, tindakan, pengamatan, dan refleksi. Dalam penelitian ini peneliti tidak bekerjasama dengan siapapun, kehadiran peneliti sebagai guru di kelas sebagai pengajar tetap dan dilakukan seperti biasa, sehingga siswa tidak tahu kalau diteliti. Dengan cara ini diharapkan didapatkan data yang seobjektif mungkin demi kevalidan data yang diperlukan.

Tahapan-tahapan dalam siklus terdiri atas 4 tahapan, yaitu: Perencanaan Tindakan, Pelaksanaan Tindakan, Pengamatan dan Refleksi. Sebelum; melaksanakan tindakan peneliti melakukan persiapan awal, yaitu : minta izin Kepala Sekolah untuk melakukan penelitian, menyusun rencana pembelajaran, dan mempersiapkan instrumen penelitian.

\section{HASIL DAN PEMBAHASAN}

\section{A. Deskripsi Kondisi Awal}

Kondisi awal sebelum tindakan, dapat peneliti sampaikan melalui tabel daftar nilai tugas siswa pada pembelajaran IPA, sebanyak dua kali.

Tabel 1. Daftar Nilai Siswa Pra Siklus

\begin{tabular}{|c|l|c|c|}
\hline No & \multicolumn{1}{|c|}{ Uraian } & Tugas 1 & Tugas 2 \\
\hline 1 & Nilai terendah & 50 & 60 \\
\hline 2 & Nilai tertinggi & 70 & 70 \\
\hline 3 & Nilai rata-rata & 62 & 71 \\
\hline 4 & KKM & 70 & 70 \\
\hline
\end{tabular}

Berdasarkan tabel di atas dapat diketahui bahwa kondisi awal siswa sangat rendah. Dengan dua kali tugas pembelajaran IPA nilai rata- rata kelas tugas 1 hanya 62 dan tugas 2 hanya 71. Kondisi awal yang demikian salah satu sebabnya adalah belum digunakannya Lembar Kerja Siswa (LKS) dalam pembelajaran IPA untuk menunjang alat pembelajaran yang digunakan.

\section{B. Deskripsi Hasil Siklus 1}

1. Perencanaan Tindakan

Perencanaan siklus I sudah matang semua perangkat yang diperlukan sudah tersedia. Yang akan melaksanakan tindakan pada Siklus I adalah peneliti yang sekaligus sebagai guru Kelas IV. Guru teman sejawat dan Kepala Sekolah SDN 61 Karara Kota Bima bertindak sebagai pengamat/observer.

\section{Pelaksanaan Tindakan}

Tindakan I berupa pembelajaran IPA pada Standar Kompetensi Mengidentifikasi Fungsi Organ Tubuh Manusia dan Hewan. Pembelajarannya 
dilakukan pada saat jadwal pelajaran Ilmu Pengetahuan Alam sehingga tidak mengganggu kegiatan belajar mengajar yang sudah direncanakan sesuai denggan program semester.

\section{Hasil Pengamatan}

Pelaksanaan tindakan secara umum sudah sesuai rencana yang dibuat. Pemberdayaan Lembar Kerja Siswa yang dibuat guru pada pelajaran IPA dengan Standar Kompetensi Mengidentifikasi Fungsi Organ Tubuh Manusia dan Hewan yang digunakan dalam pembelajaran dapat menarik minat siswa. Hanya saja konsentrasi siswa agak terganggu karena ada orang lain dalam kelas, yaitu observer. Siswa merasa diamati.

\section{Refleksi}

Hasil refleksi siklus1 ditemukan beberapa hambatan. Dengan adanya siswa yang ribut dan tidak aktif di dalam kelompok, peneliti perlu memberikan motivasi dan variasi yang lebih banyak pada kegiatan berikutnya. Hal yang mungkin dapat dilakukan adalah dengan memperbanyak pemberian tanya jawab, dan metode pembelajaran yang lain pada siklus berikutnya. Dengan adanya tanya jawab antara siswa dan guru/peneliti serta mencari metode pembelajaran yang tepat, diharapkan siswa akan lebih tertarik dan giat dalam melaksanakan tugas yang diberikan guru. Menyikapi reaksi siswa pada siklus I, yaitu siswa merasa diamati sehingga ada perasaan terganggu, maka pada kegiatan observasi berikutnya kegiatan pengamatan/observasi dilakukan dari luar sehingga dapat memberikan kebebasan/keleluasaan pada siswa untuk mengerjakan tugas Lembar Kerja Siswa (LKS).

\section{Deskripsi Hasil Siklus 2}

\section{Perencanaan Hasil Tindakan}

Perencanaan siklus 2 sudah matang semua perangkat yang diperlukan sudah tersedia. Pelaksanan tindakan sama dengan siklus I yaitu guru sebagai peneliti. Alat pembelajaran yang digunakan berupa pemberdayaan Lembar Kerja Siswa yang dibuat guru. Guru teman sejawat dan Kepala Sekolah bertindak sebagai observer. Sebagai usaha memperbaiki kekurangan yang muncul pada siklus 1, peneliti mengubah metode pembelajaran dari kelompok menjadi duduk berpasangan, selanjutnya berusaha memberikan motivasi yang lebih banyak dan mengadakan tanya jawab antara guru dan siswa, guru/peneliti lebih banyak memberikan bantuan kepada siswa yang kurang mampu sedangkan pengamatan dilakukan dari luar kelas.

\section{Pelaksanaan Tindakan}

Tindakan II berupa pembelajaran IPA dengan standar kompetensi mengidentifikasi fungsi organ tubuh manusia dan hewan, dengan pemberdayaan Lembar Kerja Siswa (LKS) melalui metode diskusi berpasangan. Sebagaimana pada tindakan siklus I, pembelajarannya dilakukan pada saat jadwal pelajaran Ilmu Pengetahuan Alam sehingga tidak mengganggu kegiatan belajar mengajar yang sudah direncanakan sesuai dengan program semester. Guru teman sejawat dan Kepala Sekolah menjadi observer di luar kelas.

\section{Hasil pengamatan}

Setelah peneliti melakukan refleksi terhadap proses pembelajaran dan hasil belajar, ternyata selama proses pembelajaran terutama saat mengerjakan Lembar 
Kerja Siswa (LKS) dari 17 orang siswa, terdapat 3 orang siswa dengan tekun mengerjakan tugas dan 6 orang siswa nampak tidak tekun mengerjakan tugas. Setelah hasil kerja siswa diteliti sudah ada peningkatan hasil belajar siswa untuk mengidentifikasi fungsi organ tubuh manusia dan hewan .

Pada siklus ke 2 ini jumlah siswa yang serius mengerjakan tugas bertambah dan hasil tugas juga sudah lebih baik. Siswa sudah menunjukkan perilaku yang bebas karena merasa sudah tidak ada yang mengamati.

\section{Refleksi}

Hasil refleksi siklus II beberapa hambatan yang muncul pada tindakan sebelumnya sudah tidak muncul lagi. Kegiatan mengerjakan tugas pada Lembar Kerja Siswa berjalan cukup lancar, hasil belajar siswa lebih baik daripada sebelumnya. Mencari jawaban dan contoh-contoh pada tugas Lembar Kerja Siswa (LKS) dapat dijawab sesuai dengan harapan guru/peneliti. Suasana kelas sudah kelihatan lebih tertib dan nyaman, sehingga proses pembelajaran dapat berlangsung sesuai dengan yang diharapkan.

\section{Pembahasan/Diskusi}

Setelah dilakukan tindakan, yaitu peneliti menggunakan pemberdayaan Lembar Kerja Siswa (LKS) dalam pembelajaran mengidentifikasi fungsi organ tubuh manusia dan hewan secara nyata dapat terlihat dari hasil pembelajaran siswa meningkat. Hal ini dapat dilihat dari hasil test 1 dan test 2 lebih baik nilainya bila dibandingkan dengan kondisi awal.

Aktivitas siswa dalam kelas ternyata memerlukan kebebasan/keleluasaan. Apabila kegitan yang sudah dilaksanakan sehari-hari diubah, siswa merasa kurang nyaman. Kehadiran guru atau orang lain dalam kelas menyebabkan terjadinya gangguan psikis pada siswa.

Pemberdayaan Lembar Kerja Siswa (LKS) dalam pembelajaran IPA, khusunya mengidentifikasi fungsi organ tubuh manusia dan hewan memiliki pengaruh/efek positif pada siswa. Dengan adanya tugas yang jelas di dalam Lembar Kerja Siswa, gagasan dan pendapat yang akan dikemukakan dapat dibuat secara sistematis sehingga membantu peningkatan siswa dalam mengelompokkan pengetahuan yang sedang dipelajari itu ke dalam fakta, data, konsep, simbol, dan hubungan dengan konsep yang lain, sehingga pemahaman produk dan konsep dalam Ilmu Pengetahuan Alam akan lebih baik.

\section{Tindakan}

Setelah dilakukan tindakan pada siklus 1 dan 2 maka tindakan peneliti dalam upaya meningkatkan pembelajaran IPA pada standar kompetensi mengidentifikasi fungsi organ tubuh manusia dan hewan dengan memberdayakan Lembar Kerja Siswa (LKS) sangat efektif. Hal ini dapat dilihat dari hasil penilaian pada siklus 1 dan 2. (nilai pada daftar tabel selanjutnya)

\section{Proses Pembelajaran}


Tabel 2. Ringkasan Proses Pembelajaran Siklus 1 dan Siklus 2

\begin{tabular}{|l|l|l|l|l|}
\hline No & Kondisi awal & Siklus 1 & $\begin{array}{l}\text { Siklus 2/kondisi } \\
\text { akhir }\end{array}$ & $\begin{array}{l}\text { Refleksi kondisi } \\
\text { awal ke kondisi } \\
\text { akhir }\end{array}$ \\
\hline 1. & $\begin{array}{l}\text { Masih banyak } \\
\text { siswa yang } \\
\text { kurang } \\
\text { bersemangat } \\
\text { dan tidak aktif } \\
\text { dalam } \\
\text { menerima } \\
\text { pembelajaran. }\end{array}$ & $\begin{array}{l}\text { Siswa yang pasif } \\
\text { dalam } \\
\text { pembelajaran } \\
\text { berkurang, ada } \\
\begin{array}{l}\text { siswa yang } \\
\text { mengerjakan } \\
\text { LKS sambil } \\
\text { bermain-main. } \\
\text { Kreatifitas siswa } \\
\text { mulai nampak. }\end{array}\end{array}$ & $\begin{array}{l}\text { Siswa aktif } \\
\text { pembelajaran, } \\
\text { tidak ada yang } \\
\text { bermain-main. } \\
\text { Anak terlihat } \\
\text { antusias dalam } \\
\text { pembelajaran. }\end{array}$ & $\begin{array}{l}\text { Dari kondisi awal } \\
\text { ke kondisi akhir } \\
\text { terdapat } \\
\text { peningkatan } \\
\text { keaktifan siswa } \\
\text { dalam proses } \\
\text { pembelajaran } \\
\text { mengidentifikasi } \\
\text { fungsi organ tubuh } \\
\text { manusia dan hewan }\end{array}$ \\
\hline
\end{tabular}

\section{Hasil Belajar}

Tabel 3. Ringkasan Hasil Belajar Siklus 1 dan Siklus 2

\begin{tabular}{|c|c|c|c|c|}
\hline No & Kon & Siklv & $\begin{array}{c}\text { Siklus 2/kondisi } \\
\text { akhir }\end{array}$ & \begin{tabular}{|c|} 
Refleksi kondisi \\
awal ke kondisi \\
akhir
\end{tabular} \\
\hline 1 & $\begin{array}{l}\text { Tugas } \\
\text { Pembelajaran } \\
\text { mengidentifikasi } \\
\text { fungsi organ } \\
\text { tubuh manusia } \\
\text { dan hewan pada } \\
\text { kondisi awal, } \\
\text { nilai terendah } 50 \\
\text { Nilai tertinggi } 70 \\
\text { Nilai rata-rata } 62\end{array}$ & $\begin{array}{l}\text { Tugas } \\
\text { Pembelajaran } \\
\text { mengidentifikasi } \\
\text { fungsi organ } \\
\text { tubuh manusia } \\
\text { dan hewan pada } \\
\text { siklus 1, } \\
\text { nilai terendah } 60 \\
\text { Nilai tertinggi } 95 \\
\text { Nilai rata-rata } 67\end{array}$ & \begin{tabular}{|l} 
Tugas \\
Pembelajaran \\
mengidentifikasi \\
fungsi organ \\
tubuh manusia \\
dan hewan pada \\
siklus 2, \\
nilai terendah 65 \\
Nilai tertinggi 100 \\
Nilai rata-rata 84
\end{tabular} & \begin{tabular}{|l|} 
Dari kondisi \\
awal ke kondisi \\
akhir terdapat \\
peningkatan \\
hasil belajar \\
dari rata-rata 67 \\
menjadi 84
\end{tabular} \\
\hline
\end{tabular}

\section{E. Hasil Tindakan}

Berdasarkan pembahasan proses pembelajaran dan hasil belajar, dapat dilihat bahwa hasil tindakan dalam pembelajaran menunjukkan adanya peningkatan. Hal ini dapat dilihat pada tabel di atas. Hasil Tindakan. Kondisi awal ke kondisi akhir terdapat peningkatan hasil belajar dari rata-rata 67 menjadi 84 . Pada proses pembelajaran juga terdapat peningkatan. Pada kondisi akhir siswa lebih aktif dalam pembelajaran Ilmu Pengetahuan Alam dengan standar kompetensi mengidentifikasi fungsi organ tubuh manusia dan hewan.

Suasana kelas menjadi lebih tertib dan aman dan terkendali, tidak ada lagi siswa yang bermain-main dan bermalas-malasan, mereka menunjukkan antusias yang 
lebih baik dari sebelumnya. Hal ini terlihat dari hasil pengamatan kepala sekolah dan teman sejawat yang melakukan observasi.

\section{KESIMPULAN}

Pemberdayaan Lembar Kerja Siswa (LKS) terutama dirancang dan dibuat guru memperhatikan karakteristik siswa di kelas dapat meningkatkan kemampuan pembelajaran mengidentifikasi fungsi organ tubuh manusia dan hewan dalam pembelajaran Ilmu Pengetahuan Alam (IPA). Yakni terlihat dari nilai rata-rata siswa pada kondisi awal 62, nilai rata-rata siklus satu 67 dan pada siklus dua menjadi 84. Hal ini telah melampaui KKM 70. Pemberdayaan Lembar Kerja Siswa (LKS) dapat meningkatkan kualitas pembelajaran mengidentifikasi fungsi organ tubuh manusia dan hewan dalam pembelajaran Ilmu Pengetahuan Alam (IPA) apalagi jika dipadukan dengan pendekatan pembelajaran pakem dan penggunaan multi metode (ceramah, tanya jawab, pemberian tugas, dan unjuk kerja), sehingga pembelajaran lebih menarik dan bermakna. Dengan demikian pemberdayaan Lembar Kerja Siswa (LKS) dapat meningkatkan kualitas pembelajaran mengidentifikasi fungsi organ tubuh manusia dan hewan bagi siswa Kelas V semester II SDN 61 Karara Kota Bima.

\section{DAFTAR PUSTAKA}

Achmadi. (1996). Tujuan Lembar Kerja Siswa, dalam http://www.kampusinfo.com/2012/10.pengertian-LKS.html./diakses06 Sep 2013;

Abdul, Majid. (2006). Perencanaan Pembelajaran. Bandung: Remaja Rosdakarya;

Depdikbud. (199) Syarat-Syarat Lembar Kerja Siswa, dalam; http://www.kampusinfo.com/2012/10.pengertian-LKS.html./diakses06 Sep 2013;

Trianto. (2008). Pengertian Lembar Kerja Siswa, dalam; http://www.kampusinfo.com/2012/10.pengertian-LKS.html./diakses06 Sep 2013;

Departemen Pendidikan Nasional, KurikulumTingkat Satuan Pendidikan. (2006). Sumber Ilmu; Departeman Pendidikan Nasional, Standar Kompetensi dan Kompetensi Dasar Ilmu Pengetahuan Alam alam SD/MI.Jakarta :

Depdiknas; Gorman dalam Bambang dan Paidi. (2002), Kemampuan Siswa, dalam; http://Smatalzind.blogsport.com/2012/04/karakteristik-pembelajaran-ipadisdhtml, diakses, 06 Sep 2013;

Hadi Sukamto. (1992). Kegunaan Lembar kerja siswa. http://www.kampusinfo.com/2012/10.pengertian-LKS.html./diakses06 Sep 2013;

Hamzah, Uno. (2006). Perencanaan Pembelajaran. Jakarta: BumiAksara http://smartalzind.blogspot.com/2012/04/karakterisrik-pembelajaran-ipadisd.htmldiakses, 06 Sep 2013;

KTSP Berkarakter Tingkat Satuan SD/MI, Perkembangan kognitif pembelajaran IPA, http://www.geocities.com/no vyant/Ss-inisiasi-sem2/inisiasipengembangan-pembelajaran-ipa-disd-html, diakses 06 sep 2013; 
Prof.Dr.H.Mohammad Asrori, MPd. (2009), Penelitian Tindakan Kelas, Bandung: Wacana Prima;

PrimaSumadi Suryabrata. (2002). Psikologi Pendidikan. Jakarta: PT Raja Grafindo Persada.;

Rosmala Dewi. (2006). Pengertian Belajar Menurut Para Ahli, dalam http://herrystw, wordpress.com/2011/05/23/pengertian-belajar-menurut-para-ahli, diakses, 06 sep 2013;

Suharsimi Arikunto. (1993). Manajemen Pengajaran secaraManusiawi. Jakarta: Rineka Cipta;

Tim Kreatif Guru. (2013), Ilmu Pengetahuan Alam SD/MI Kelas V, Jakarta:Bumi Aksara 